\title{
Tentmaking ministry in the Hervormde Kerk in Suidelike Afrika: Solution or problem $^{1}$
}

\author{
Matsobane J Manala \\ Department of Practical Theology \\ University of South Africa
}

\begin{abstract}
Tentmaking ministry is a recommended interim measure which, for some churches is a permanent measure in respect of church ministry. Churches operating in poorer countries or in countries where sections of societies find themselves in financial crisis, resort to this kind of arrangement for service provision. In order for the church to effectively fulfil its mission in situations of abject poverty, it has become necessary to implement new methods and patterns of ministry. The tentmaking ministry is one such ministry pattern. The previous theory regarding ministry does not appear to measure up to new realities. Many churches, and recently, the Hervormde Kerk in Suidelike Afrika, have adopted the tentmaking ministry. In response to the challenge within to continuously test the relationship between theory and praxis, this article aims to evaluate the tentmaking ministry as applied in the Hervormde Kerk in Suidelike Afrika.
\end{abstract}

\section{INTRODUCTION}

At its fourth General Church Assembly held in 1988, the Hervormde Kerk in Suidelike Afrika (HKSA) ${ }^{2}$ adopted the implementation of tentmaking ministry in response to the financial dilemma the church was facing. The reality has also dawned on the HKSA that some other innovations would have to be considered. The interest in tentmaking ministry seems to have become a

\footnotetext{
${ }^{1}$ The article has been reworked in the light of two articles with the same topic published in "Montshafatsi" (Official Mouthpiece of the HKSA), the first one in Volume 18(1) June 2002 and the second in Volume 18(2) October 2002.

2 "Hervormde Kerk in Suidelike Afrika" (acronym HKSA), which is loosely translated as "Reformed Church in Southern Africa", refers to the Reformed Church that was established in 1923 in the then Province of Natal in South Africa, subsequently expanded in close relationship with the "Nederduitsch Hervormde Kerk van Afrika".
} 
general feature in many so-called Third World churches that used to rely heavily on the financial support of the richer missionary churches.

In almost all cases where tentmaking ministry is adopted, it is prompted by financial problems. Heyns (1993:205) attests to this: "Of late there has been a fresh surge of interest in tentmaker ministries. The reason for this is economic rather than theological. The financial problems of First World churches, and the financial dependence of those in the Third World, have evoked a new interest in tentmaking ministry." Perhaps it should be added that the interest in tentmaking ministry is often not voluntary, especially as far as the poorer churches are concerned.

In 1991 and in the light of well-formulated recommendations aimed at facilitating further discussion and implementation, the fifth General Church Assembly of the HKSA, took the matter one step further. The goal was to provide ministers of the church with some extra income, thereby improving their livelihood. This, the church believed, would ensure continued commitment to congregational ministry, while providing some joy and a measure of material satisfaction as well. Since then, scores of ministers of this church have engaged in the tentmaking ministry in pursuance of the envisaged improved livelihood which it was thought, would encourage commitment to the congregational ministry. African Initiated Churches provide a good example of how tentmaking ministry can be successfully implemented (cf Heyns 1993:206).

The increase in the number of ministers who take up tentmaking ministry is unprecedented. In view of this increased engagement of the church's clergy in tentmaking ministry, it is, in my opinion, appropriate to reflect on and evaluate the practice of tentmaking ministry within the HKSA and this is precisely what this article sets out to do. It reflects on the practice of tentmaking in the light of the following questions: What is tentmaking ministry? What are reasons for engaging in tentmaking ministry? What is the impact of tentmaking ministry on service provision and progress within the HKSA? Has it provided a solution or has it created problems for the church's ministry? How can the practice of tentmaking ministry be best utilised to correct possible flawed implementation thereof?

\section{TENTMAKING MINISTRY - DEFINITION AND IMPLICATIONS}

The concept "tentmaking ministry" usually refers to the pastoral service or service of the Word by the pastor or servant of the Word who, for one reason or another, also has a so-called secular occupation or is involved in a secular enterprise. This is not new. The apostle Paul engaged in the making of tents 
to cater for his and his companions' needs. The concept "tentmaking ministry" has its origins in this part-time trade of Paul (Heyns 1993:205). Tentmaking ministry can be defined as a ministry in which a minister, while working in and for a congregation, is partially or totally responsible for his or her own sustenance (cf Raubenheimer 1986:5, Pienaar 1986:5). For Dreyer (1987:529) the description of tentmaking ministry lies in its relation to full-time ministry. Tentmaking ministry in Dreyer's view then, is a ministry of the church to which a minister dedicates only part of the required time while simultaneously working in another vocation that partially or wholly provides for his or her sustenance. In other words, tentmaking ministry , as it is currently suggested and practised, is a part time ministry. Paul, however, resorted to his tentmaking trade as a token and an act of sacrifice. He namely sacrificed his right of receiving support from the congregation(s). But unlike the current tentmaking practice, Paul's tentmaking did not imply part-time ministry on his part. Theron (1986:5) points out that Paul's situation was exceptional, because he was not in a full-time tentmaking ministry, as some congregations assisted in providing for his needs (cf Phlp 4:15 \& Rm 15:24). Therefore, his tentmaking ministry did not constitute part-time work in the area of his core task, that is, the proclamation of the gospel. There are valid reasons, not all of which are economic in nature, for Paul's engagement in tentmaking ministry. These reasons will be dealt with in more detail at a later stage.

To my mind there could, however, be a problem with the name: "tentmaking ministry". The problem lies therein that it tends to overemphasise the making of tents rather than the proclamation of the gospel, which is the core vocation of the apostle/minister. It could erroneously create the impression that Paul was primarily engaged in the making of tents, rather than the proclamation of the gospel. It should be noted that other terms are also used to describe this form of ministry engagement, such as, "non-stipendiary ministry, voluntary ministry, honorary ministry, and supplementary ministry" (Francis 1998:xv). In my view a more accurate description would be, as Francis (1998:xv) suggests, that of "self-supporting ministry", as it describes more accurately the method by which the ministry is maintained or supported, that is, through the pastor's self-supporting initiatives. Such self-supporting ministry would lessen the financial burden on the congregation.

Despite the shortcomings referred to above, the description tentmaking ministry rather concretely expresses the creativity with which the gospel is served, even in the face of economic deficiency. This statement has to be qualified by the acknowledgment that an unbalanced emphasis on the making of tents to the detriment of the proclamation of the gospel could be responsible for a flawed implementation of the practice, resulting in dereliction 
of duty (pastoral services). The $5^{\text {th }}$ General Church Assembly of the HKSA in 1991 was aware of the fact that this could in fact happen. It is for this reason that the point for discussion brought before/tabled at the assembly, included a reflection on reasons for or against the approval of tentmaking ministry. I shall deal with these, starting with reasons against and then focusing on the reasons for tentmaking ministry in the subsequent sections of this article.

\section{REASONS AGAINST APPROVAL OF ADOPTION OF TENTMAKING MINISTRY}

The following are given as reasons that could highlight the nature and extent of possible negative consequences arising from the adoption and implementation of tentmaking ministry by the HKSA (see the following version of the HKSA Agenda [1991:52] and the HKSA Minutes [1991:43]):

a) It would adversely affect the church's ministry as ministers could concentrate on their other/secular employment at the expense of their core vocation, which should be their pastoral work and responsibilities.

b) Ministers would not be available when congregations need them, and the attendance of church meetings, seminars, workshops, and so forth may suffer as a result.

c) Moral standards could be adversely affected as ministers would be exposed to numerous temptations in other fields in the secular world.

d) A tendency to serve Mammon rather than God (Matt 6:24) could be encouraged. Economic glamour could blind the servants of God.

The threat of ministers being trapped in self-enrichment at the expense of the ministry is a reality that cannot be denied. Allen (1998:56) writes: "That there was a danger lest clergy who engaged in trades and businesses might busy themselves over much in money making is only too obvious." The danger of the biased attention of the clergy was and always will be a potential disruptive factor in this kind of ministry.

It has indeed been observed that ministers' availability for services, meetings, seminars and workshops has drastically declined since the HKSA's embracement of tentmaking ministry. Reports to this effect have served before the moderamen (Church's National Executive Committee) and the discussion thereof has taken much of that committee's planning and 
development time. Despite the fact that so much time was dedicated to efforts to resolve problems of this nature, the situation still prevails. More than twenty ministers were for example absent from the General Church Assembly (GCA), held in 2000. A similar situation had arisen in respect of planned seminars and workshops that took place prior to the GCA. As can be seen from the above list of reasons against such ministry, the church had in fact anticipated this situation.

The realities of our times, however, have compelled the church to also consider the other side of the coin, in order to treat the issue of tentmaking in a balanced way. For this reason the GCA also considered reasons in favour of the introduction of tentmaking ministry, which are dealt with here below:

\section{REASONS IN FAVOUR OF EMBRACEMENT OF TENTMAKING MINISTRY}

As per the HKSA, Agenda (1991:52) and the HKSA, Minutes (1991:43) the reasons that support and justify the introduction and approval of tentmaking ministry as a ministerial pattern to be followed in present times, are the following:

a. The $4^{\text {th }}$ General Church Assembly (1988) had decided in favour of the tentmaking ministry. The present Assembly was therefore implementing the previous Assembly's decision in the light of studies undertaken.

b. The economic slump and financial crisis the church is experiencing, are real and church members unfortunately have not anticipated such a financial crisis. Members have always relied on the financial support of the Nederduitsch Hervormde Kerk van Afrika (NHKA) and the announcement of the latter's own financial problems came rather unexpectedly.

c. The financial needs of ministers and their families, such as food, clothing, education of children, medication, and so forth, are non-negotiable essentials. The stipend scale for ministers, which is determined by the subsidy provided by the NHKA, is insufficient and is scheduled to decline even further, with the possibility of it being withdrawn altogether, looming?

d. The NHKA, the subsidy-provider, has itself, by means of a decision of its General Church Assembly, granted permission to its own ministers to engage in tentmaking ministry and has also in principle agreed that the HKSA could consider the possibility of embracing tentmaking ministry. 
Reasons in favour of the embracement of tentmaking ministry were rather impelling, for they address the existential needs of ministers and the inability of congregations to financially maintain pastoral stations. The practice of tentmaking ministry as a ministry pattern is already being regarded as a permanent feature of church life by some. A full-time clergy is currently being viewed as an un-affordable luxury for the church. That will eventually disappear. In this regard Chadwick (1998:81) states:

But face the facts. Already the old concept of a full-time clergy is becoming outmoded. Many of our clergy are no longer full-time pastors. Many are spending a fair proportion of their week in washing up, cleaning rooms, supplementing their incomes by market-gardening. You cannot have a full-time clergy unless their economic status relieves them from the necessity of worrying about their homes and livelihood.

Dreyer (1987:545), writing in the context of the Nederduitsch Hervormde Kerk van Afrika (NHKA), ${ }^{3}$ acknowledged that due to financial demands it would be very difficult for congregations to afford a full-time pastoral station. He therefore advises that tentmaking ministry could provide a solution in such situations. For this reason the NHKA finally accepted tentmaking ministry as a bridging mechanism in a time of the church's financial crisis.

Financial demands have also necessitated the Hervormde Kerk in Suidelike Afrika to consider and ultimately embrace tentmaking ministry. Problems associated with the occasional unavailability of ministers in congregations, at church meetings and other church businesses have become unavoidable. This situation points to the fact that the ideal of tentmaking ministry does not necessarily merge with the reality of demands arising from extra-ecclesiastical employment. What can be done to ensure achievement of the threefold goal of sustenance of the church's ministers, progress on service provision and healthy church administration? Presently, the church has elected to embrace tentmaking as a possible solution to the financial crisis it faces. As far as a balanced implementation is concerned, it would be advisable for the church to learn from Paul's own engagement in selfsupporting ministry.

\footnotetext{
3 "Nederduitsch Hervormde Kerk van Afrika", (acronym NHKA), is loosely translated as "Dutch Reformed Church of Africa" and refers to the white Reformed Church that played the role of "guardian" in the life and work of the "Reformed Church in Southern Africa".
} 


\section{REASONS FOR PAUL'S ENGAGEMENT IN TENTMAKING MINISTRY}

A brief look at Paul's reasons for engaging in tentmaking ministry may indeed help us in our efforts towards achieving a balanced understanding of the practice. It must however be borne in mind that the circumstances that led to the adoption of this ministry differ considerably in the two instances. I In Paul's case the reason for engaging in this ministry was mainly theological, while the HKSA's decision to embrace tentmaking ministry is mainly economical. If this is an accurate assessment, then the two different points of departure will have to converge in order to achieve congruence between the theological and economic needs of the church of Christ. This would be the topic of future research. Let's for the moment focus on the reasons for Paul's engagement in tentmaking ministry. Paul decided to take up his tentmaking trade as a token of sacrifice. He sacrificed his right of receiving sustenance from the congregation for the following reasons:

- $\quad$ Firstly, Paul's act was an act of facilitating transmission of the gospel. He did not want his requirements for sustenance, to stand in the way of the gospel (1 Cor 9:12). The apostle toiled for his sustenance so that he would not be a burden to anyone in the course of preaching the gospel ( 1 Th $2: 9 ; 2$ Th $3: 8$ ). His action was therefore taken for the sake of the gospel and not for self-aggrandisement. He did not want to hinder the gospel of Jesus Christ through his claims, albeit legitimate, for sustenance. This is quite understandable, especially in view of the fact $t$ that Paul was mainly in a missionary situation, establishing and equipping congregations for their service.

- Secondly, Paul took to tentmaking ministry so that he could offer the gospel free of charge (1 Cor 9:18). The apostle exercised his tentmaking trade in order to give, rather than to receive (Ac 20:35). Paul accepted this as the basis of his tentmaking ministry. This principle the apostle wished to instil in other missionaries and pastors in Ephesus too. Paul considered it a privilege to preach the Good News without charging for it. His objective was to win as many people as possible for the Lord. To this end he sacrificed his right to receive a salary from the congregation(s). He knew this right, acknowledged it and even defended it vigorously (1 Cor 9:3-14). But the apostle sacrificed this right for the sake of the congregation which he regarded as the fruit of his labour (1 Cor 9:16). 
Although Paul in 1 Corinthians 9:16, indicated that he had no freedom or choice other than to carry out the commission of preaching the gospel, laid upon him by God, he in an inverted and illogical way, exercised his right to freedom. Yes, although Paul was, in respect of the orders laid upon him, a slave, he could, according to Hock (1998:7) exercise his freedom by preaching the gospel without charging money. Hock (1998:7) writes: "He could exercise freedom only in the manner in which he discharged his apostleship, which he did by deciding to carry out his commission to preach in Socratic fashion, that is, to offer the gospel free of charge (adapanos) (verse 18)". This way of asserting one's economic freedom was considered to be rather a noble act in the philosophical milieu. According to Hock (1998:7) Socrates once asked boastfully "Who among men is more free (eleutherioteros) than I, who accepts neither gifts nor fee from anyone?" Preaching the gospel free of charge therefore gave Paul economic freedom, of course, a freedom for which he had to pay dearly by making himself a slave of all.

- $\quad$ Thirdly, although he was aware of his rights and freedoms, he made himself a slave ... in order to win as many people as possible (1 Cor 9:19). He was not a free and salaried labourer, but was under orders to preach the gospel. Like a true slave Paul opted for forfeiture of his rights because of the way in which he understood his apostleship, namely as anagke, that is, as a necessity laid upon him by God. He understood his apostleship as something he had to do at all cost. Paul had no freedom as far as the carrying out of the commission to preach the gospel was concerned. It simply had to be carried out. In other words he, like a true slave had no choice, but to carry out the command to preach the gospel. This much is clear from Paul's statement in 1 Cor 9:16: "I have no right to boast just because I preach the gospel. After all, I am under orders to do so. And how terrible it would be for me if I did not preach the gospel".

These words of Paul's are inconsonance with what the Lord Jesus said in Luke 17:7-9 about the position of a servant:

Suppose one of you has a servant who is ploughing or looking after the sheep. When he comes in from the field, do you tell him to hurry and eat his meal? Of course not! Instead, you say to him, "Get my supper ready, then put on your apron and wait on me while I eat and drink; after that you may have your meal." The servant does not deserve thanks for obeying orders, does he? It is the same with 
you; when you have done all you have been told to do, say, "We are ordinary servants; we have only done our duty."

(Lk17:7-9)

Paul's understanding of his apostleship as slavery echoes Jesus' contemporary understanding of the master-servant relationship.

Paul's taking up of a slavish trade of making tents brought him loss of status, hence his words, “... but I make myself everybody's slave ..." (1 Cor 9:19), and "Did I commit sin by demeaning myself ... because I preached God's gospel to you free of charge" (2 Cor 11:7)?. Given the circumstances it was, however, the best way for him to attain economic self-sufficiency. What Paul viewed as demeaning could point to both his taking on of tentmaking ministry and his acceptance of gifts from other congregations, for example from the Macedonian church (2 Cor 11:9). In order for him to carry out his mission-commission effectively, without burdening those to whom he was preaching the gospel, Paul had to accept the status of a slave and a beggar.

Fourthly, Paul exercised his trade in order to set a good example with regard to industriousness (Ac 20:35; 1 Cor 4:12, 16; 2 Th 3:9). According to Francis (1998:41) Paul's correspondence in 1 Thessalonians 4:11 (cf 2 Th 3:12) about his self-supporting or tentmaking ministry, "exhorts his readers in a three-fold way: 'to live quietly, to mind one's own affairs and to work with one's hands'". In this way Paul's teaching praxis carried with it a moral character. Allen (1998:54) alludes to a practice in the early church of leading by example as a way of teaching diligence. Allen (1998:54) cites the source known as the Second Book of the Apostolic Constitutions, with reference to the apostolic example of extreme diligence: "We ourselves, besides our attention to the word of the gospel do not neglect our inferior employments. For some of us are fishermen, some tentmakers, some husbandmen, so that we may never be idle." Stories of hard work by the clergy in the early church abound (Allen 1998:55). Idleness was probably, following Scriptural evidence, seen as undesirable and unproductive, even sinful and was to be shunned (cf Pr 19:15; Zch 11:17). Engagement in hard manual labour was therefore significant for the training of new Christians. Hard work according to Paul was also fundamental to Christian support for and assistance to the weak and the poor. All these references to his preference for and participation in hard work are for Paul an affirmation of his apostolic office. In Paul hard work as an apostolic affirmation finds both edification and benevolent value. 


\section{IMPORTANT FACTS EMANATING FROM REFLECTION ON PAUL'S TENTMAKING MINISTRY}

The following points in respect of Paul's tentmaking ministry are worth noting:

a. Paul's engagement in tentmaking ministry was for the sake of Christ and his gospel.

b. Paul declared to the churches that he would not take sustenance from them as long as he was able to make ends meet. But he also insisted on teaching congregations that it was his right and that of the other apostles to receive sustenance from them.

c. Paul was always available to preach the gospel and to make disciples with a view to the expansion of the church of Christ and of the kingdom of God.

d. It is also clear that Paul took to tentmaking ministry out of his compassion for the congregation. He wanted to alleviate the financial burden on congregants and he wanted to present them with a practical lesson on hard work.

e. Paul's earnings from his self-supporting ministry were being supplemented by gifts from other congregations, such as the one in Macedonia.

\section{THE IMPACT OF TENTMAKING MINISTRY ON SERVICE PROVISION AND PROGRESS IN THE HKSA}

That tentmaking ministry has an impact on the functioning of the church's service delivery machinery cannot be denied. However, what needs to be determined is exactly what that impact is and to what extent it advances or impedes the functioning of the church. There are instances where the engagement of ministers of the HKSA in tentmaking ministry is experienced as positive and desirable and others where the opposite is experienced. Tentmaking ministry appears to be successful in those churches that have never had the luxury of full-time ministers. Heyns (1993:214) notes with appreciation the success of tentmaking ministry among the African Independent Churches. In this regard he alludes to the dynamic growth in these churches, which he believes could in part be ascribed to this pattern of ministry. Heyns (1993:214) also refers to the successful use of tentmaking ministry by Latin American Protestant Churches, citing Lowery (1976). It does seem therefore that, properly applied, tentmaking ministry could have a positive impact on other denominations as well. Let me now deal with the task I have set myself, namely to gauge the impact of tentmaking ministry in the 
HKSA by looking at the advantages and disadvantages of the practice of tentmaking ministry as it emerges.

\subsection{Advantages of tentmaking ministry in the HKSA}

As has already been stated, certain advantages have been observed since the engagement of pastors of the HKSA in tentmaking ministry. I do not pretend to be conversant with the situation in all congregations of the HKSA and cannot therefore claim to produce results of a scientific study. I can only list those advantages that I have observed in the few congregations I had the opportunity of interacting with. Of course, in my capacity as the church's administrative officer until recently, I have had the privilege of being at the centre of this church's life and work. During my term I could glean some information and gain insight into issues affecting different congregations throughout the church. The following advantages are noteworthy:

- $\quad$ Tentmaking ministry relieves poor congregations of their financial burden

Congregations that would otherwise lack fundamental services because of their inability to afford those services, continue to receive vital pastoral services. Congregants are indeed not suffering from spiritual starvation. The little financial resources such congregations have can be utilised for other essential payments, such as municipal services.

- $\quad$ Meeting of the pastor's financial needs which the church cannot afford Tentmaking ministry has made it possible for the church to grant ministers permission to be otherwise employed while still rendering pastoral services in the church. In this way, the pastor's financial needs are being met, albeit partly. Services rendered to church are rendered at almost no cost. The costs incurred by the church with regard to services rendered by the pastor, can safely be described as an allowance or compensation to cover the pastor' actual expenses associated with rendering the service to the church. It does mean that the pastor is still making sacrifices in the service of the Lord.

- $\quad$ Ministers are exposed to work and life outside the church The pastor gains experience and knowledge not normally offered by the church environment. These experiences and knowledge are often enriching and both the individual pastor and the congregation stand to benefit from it. Tentmaker pastors effectively live among the people on 
a day to day basis. This undoubtedly intensifies the relationship between the pastor and the people he/she serves and increases the effectiveness of the ministry. Broache (1998:172) cites the words of $A B$ Peters with regard to the positive impact on ministry by those who work amidst other people in secular settings: "To be successful among the people we must be one among them in everyday life."

- $\quad$ The relationship between pastor and congregation is brought into proper perspective

Through this form of ministry the congregation comes to realise that the pastor is as human as anyone else. There has been a tendency among certain congregations to treat the pastor as "congregational property" that can be moved and manipulated at will, simply because of being on the congregation's payroll. At the same time the fact that the pastor is earning a livelihood outside the church, can defuse a potential unhealthy tension in the relationship between him or her and the congregation. They (pastor and congregation) meet and interact as members of the church and as co-workers in the Vineyard of the Lord, a relationship/partnership where no one owes the other anything. The relationship ceases to be strictly that of an employer-employee and proceeds to become a human-to-human relationship, which, to my mind, is undoubtedly healthier.

- $\quad$ There is every possibility that pastors who do not work for a salary, will have the satisfaction of working for the Lord, for the love of the kingdom rather than for the love of money In 1 Peter 5:1- 4, elders are advised to work willingly and voluntarily:

... I appeal to you to be shepherds of the flock that God gave you and to take care of it willingly, as God wants you to, and not unwillingly. Do your work, not for mere pay, but from a real desire to serve. Do not try to rule over those who have been put in your care, but be examples to the flock. And when the Chief Shepherd appears, you will receive the glorious crown which will never lose its brightness.

(1 Peter 5:1-4)

Broache (1998:172) indicates that this type of tentmaking ministry pattern was practised in the Church of the Brethren in Germany since its inception in 1708 until late in the $19^{\text {th }}$ century when the first pastors were hired by individual congregations. Tentmaking ministry is seen as creating a vital opportunity for the minister to interact at his workplace 
with "ordinary" Christians, which factor greatly contributes to the success thereof.

- $\quad$ Tentmaking ministry paves the way for church's independence and healthy autonomy

Tentmaking ministry, to some extent, enables movement of the church towards economic independence and envisaged autonomy. It provides the congregation with some relief from its financial responsibilities. In this way, the congregation is assisted in strengthening its economic position.

- $\quad$ The priesthood of all the believers starts to take root in the HKSA With the responsibilities of a second job and the time demands that go with it, the tentmaker pastor obviously will not be able to be involved in all that needs to be done for the proper functioning of the congregation. The pastor and the congregation are therefore faced with the need to devise a means of building capacity for the sake of rendering and maintaining a comprehensive service. Through the tentmaker pastor practice the focus moves from the pastor as the only service provider and forces the congregation to accept co-responsibility for services. This is indeed a step in the right direction for a financially struggling church that that needs to break the dependency syndrome to become self-reliant.

\subsection{Disadvantages of tentmaking ministry in the Hervormde Kerk in Suidelike Afrika}

The fact that the engagement of ministers of the HKSA in tentmaking ministry has advantages implies that it will also have its disadvantages. I will now focus on those disadvantages that are quite problematic and could impede the efficient functioning of the church:

- $\quad$ Lack of time and capacity for effective functioning is an undeniable reality in the context of self-supporting ministry

The tentmaker pastor's time to do what is required of her or him, is very constrained. As a result, church meetings, development seminars and workshops are usually compromised. This is indeed unfortunate, because the HKSA as a poor, developing church needs the participation of all functionaries in efforts to equip and develop the church. It may very well be true that after eight hours of her or his socalled secular job, the pastor's energy is so drained that she/he is not 
able to attend to the pastoral challenges in the parish. This could be counter-productive in congregations trying to keep the tentmaker minister in the practice of her or his divine calling, while also trying to make actual progress. If a tentmaking ministry does become counterproductive, it will be totally out of step with the HKSA's Vision 2000 and beyond, the primary goal of which is the attainment of greater independence, self reliance, empowerment of the laity (members) and involvement in community development. The minister is expected to play an active part in the activities towards the realisation of this vision. But if she or he is lacking the energy to do the job, the church cannot hope to achieve its important goal.

- $\quad$ Appointment of pastors in jobs that are far away from their congregations proves to be too costly for the church Such situations prove to be quite problematic. It means that the pastor who finds him- or herself in such a situation often has to travel long distances on a daily basis to be with her or his family and congregation. This travelling leaves him/her tired and may, in the long term, lead to fatigue and burn out. In some cases the pastor may decide to live closer to the place of work during the week and only returns to the congregation and her or his family over weekends. This amounts to the congregation virtually having a weekend pastor, which is not what is needed for the congregation's edification towards the realisation of the HKSA's vision.

- $\quad$ Some pastors who are in tentmaking ministry, no longer bother to motivate and teach Christians about Christian offering The fact that she or he now gets a salary from a secular institution makes her or him lose sight of the church's objective of attaining financial independence and self reliance. It is a known fact that ministers experience great difficulty in teaching people to offer, especially in a church that for decades has relied so heavily on financial assistance and other resources from another church. A certain minister (who was a tentmaker pastor) resigned from the ministry and cited as reason, the fact that the church unduly expected him to teach people to offer, which he claimed, was not what he was trained to do. Had he not resigned, he would have been passive with regard to the responsibility he had in this regard and the church would make no progress. 
- $\quad$ Pastors in tentmaking ministry are faced with a serious temptation regarding their allegiance

Pastors who have opted for tentmaking ministry are often viewed by others as having lost interest in the church and her services. This feeling is prompted by the fact that these tentmakers are no longer able to regularly attend church meetings and other occasions as a result of their job commitments. Tentmaker pastors are forced to prove that their allegiance is still with the church. They then become despondent and find themselves faced with a choice between being contracted to the church and cutting all contractual ties with the church.

\section{PROPOSED WAYS OF APPLICATION OF TENTMAKING MINISTRY IN THE HKSA WITH A VIEW TO CORRECT EXPERIENCED FLAWS}

The last of the questions rose at the beginning of the article concerns the way forward in respect of fine-tuning the implementation of tentmaking or selfsupporting ministry. To be more precise, what needs to be established is how tentmaking ministry could be best implemented to ensure continued effective proclamation of the gospel? Put differently, the question is: How can the practice of tentmaking ministry be adapted to correct possible flawed implementation thereof?

The need to find best ways of implementation of tentmaking ministry does not in any way suggest that the initial approval was granted without due consideration. That careful consideration was given to the matter is evident from the "reasons against and affirmative reasons" recorded above, "procedures to be followed" and other serious "considerations" in terms of the choice of employment or trade (HKSA Agenda 1991:52-53). The memorandum that was tabled in this regard was accepted by the General Church Assembly (HKSA Minutes 1991:43 \& 63). The need for reconsideration is the result of continued evaluative activity. Some disadvantages in the practice of tentmaking ministry in the HKSA have been indicated, which point to ineffective service provision. According to Theron (2000:193), Zerfass provides a model that suggests the way in which church praxis can be evaluated and improved. This model suggests that praxis needs to be observed in the light of theories on which it is founded and in the light of what transpires or is necessary in the actual situation. What is required is that there should be a healthy balance between theory and praxis.

The HKSA has embraced tentmaking ministry on the basis of considerations contained in the agenda of the General Church Assembly of 1991 (HKSA Agenda 1991:52-55). The considerations therefore served as 
basis for discussion, approval and implementation of tentmaking ministry as an alternative pattern of ministry to be adopted in the context of the prevailing financial crisis. These considerations included procedures for engagement, the nature of tentmaking ministry, that is, whether it was part-time, full-time or self-employment, the type of employment, that is, whether it would affirm Christian moral standards or not, amount of time of engagement in tentmaking ministry (the minister's ability and availability to do pastoral services in addition), distance of the workplace from the congregation and the ideal of excluding members of the moderature from candidature for tentmaking ministry. It means that the General Church Assembly adopted the practice of tentmaking ministry with the understanding that applications for engagement in tentmaking ministry would be considered in the light of the abovementioned guidelines.

It unfortunately so happened that many of those pastors of the HKSA who are in tentmaking ministry landed up in full-time employment. A better option would have been for pastors to be employed on a part time basis. .. The most preferable option, as stated in the study document, would be selfemployment (HKSA Agenda 1991:54). The following reasons were given for this preference of the church:

a) The type of business a minister runs is his or her best consideration and s/he should see to it that it fits in with Christian values and that, where possible, it could even advance church ministry.

b) In certain instances the church could benefit financially from the enterprises of tentmaker pastors For example, ,a Pentecostal church pastor in Evaton, who is a building contractor and whose business is named "Mohau", with a subscript quotation from Ephesians 2:8, offers an affordable service and in the process he has built a few church buildings for his denominations.

c) Since the minister is self-employed, s/he would be in a better position to plan his or her time in such a way that church duties could be honoured. In times of congregational need s/he could re-organise the business side in such a way so as to be able to attend to church matters and to meet church obligations.

d) Over a period a tentmaker minister may have a better idea of her or his average income from her/his business undertaking and advise the church to adjust her or his salary in accordance with the scale. In this regard it is to be hoped that 
the Ananias and Saphira tragedy will serve as a reminder to act with integrity.

While it has not been possible for ministers of the HKSA to be self-employed, the fact that this type of employment could be more effective as a solution to the financial crisis in the church cannot be denied. The fact that in one's own business, one would be able to adapt your plans in case of an emergency makes this a preferred option for the church. A further plus factor in favour of the self-employment model is the fact that it is possible to assign an assistant to do the job while the pastor attends to urgent church duties. With a view to the future this option should in my opinion be further explored. Selfemployment is a viable option for those who have acquired a trade such as bricklaying, photography, video filming, and so forth. It could also make a contribution towards the job creation drive and towards building the country's economy.

\section{CONCLUSION}

This article has highlighted the dilemma in which the church finds itself. The dilemma is caused by two realities, i.e. the dire financial need of ministers and the absolute need of the church to make progress in the proclamation of the gospel and the rendering of healthy administrative services. The situation is aggravated by the incapacity of the congregation which is supposed to be the financial source from which pastoral services are to be financed. There is thus a need for capacity building in respect of the financial viability of congregations. This could be achieved through the serious engagement of pastors, deacons, all members and finance committees of congregations in practicing the viable fundamentals of Christian offering and the implementation of effective fundraising strategies. The problem at hand needs serious reflection and debate at all levels of the church. In a sense, this article is an invitation to Hervormers wherever they are to engage in a constructive debate on this important topic.

It is clear that engagement in tentmaking ministry will not only have advantages, but also disadvantages for the ministry. Thus, engagement in tentmaking ministry has both a positive and a negative impact on the church's pastoral services. By adopting an either/or approach, will not adequately address the situation. What will, to my mind, be more effective, is an and/and approach. The church needs the tentmaking ministry for its advantages and the efficient functioning of the church, for the sake of proper progress. It seems to me that the church will have to continue reflecting on this alternative form of ministry, especially focusing more and more on self-employment 
opportunities. In view of the financial problems that the church continues to face, it seems that this pattern will increasingly become a necessity.. It is also possible that this pattern could become dominant in future developments of the church's ministry.

\section{Works consulted}

Allen, R 1998. The maintenance of the ministry in the early ages of the church, in Francis \& Francis 1998:54-60.

Broach, S 1998. The emerging pastorate, in Francis \& Francis 1998:172-194.

Chadwick, O 1998. Tentmakers, in Francis \& Francis 1998:81-90.

Dreyer, T F J 1987. 'n Prakties teologiese evaluering van moontlike bedieningstrukture in die Nederduitsch Hervormde Kerk toegespits op die rol van die predikant. HTS 43, 522-555.

Francis, J M M 1998. Introduction, in Francis \& Francis 1998:xV-xviii.

Francis, J M M \& Francis, L J (eds) 1998. Tentmaking: Perspectives on self supporting ministry. Gracewing: Fowler Wright Books.

Hervormde Kerk in Suidelike Afrika, General Church Assembly, Agenda 1991:52-55. Hervormde Kerk in Suidelike Afrika, General Church Assembly, Minutes 1991:43, 60. Heyns, L M 1993. Tentmaker ministries. Practical Theology. Only study guide for PTB302-A, 204-214, in Van Wyk, A G, Theron, J P J, Heyns, L M \& Dreyer J $S$ (eds), University of South Africa.

Hock, R F 1998. Paul's tentmaking and the problem of his social class, in Francis \& Francis 1998:4-13.

Pienaar, P A 1986. Predikant se lewensonderhoud. Die Kerkbode 19 Maart, 5. Raubenheimer, O 1986. Vrae oor die tentmaking. Die Kerkbode 7 Mei, 5 \& 8.

Theron, J P J 2000. Theories, models and praxis: More concepts. Invitation to theology. Fundamental module for BTh programmes. Only study guide for CGM111-N, 184-197. University of South Africa.

Theron, S W 1986. Nuwe Testament en tentmakerbediening. Die Kerkbode, 4 Junie, $5 \& 11$. 